pag

Business School

WORKING PAPER SERIES

Working Paper

2014-596
Determinants of crop yield and profit of family farms: Evidence from the Senegal River Valley

Elodie Blanc

Aurelia Lepine

Eric Strobl

http://www.ipag.fr/fr/accueil/la-recherche/publications-WP.html

IPAG Business School

184, Boulevard Saint-Germain

75006 Paris

France

IPAG working papers are circulated for discussion and comments only. They have not been peer-reviewed and may not be reproduced without permission of the authors. 


\title{
Determinants of crop yield and profit of family farms: Evidence from the Senegal River Valley
}

\author{
Elodie Blanc (MIT) \\ Aurelia Lepine (London School of Hygiene and Tropical \\ Medicine) \\ Eric Strobl (Ecole Polytechnique \& IPAG)
}

\begin{abstract}
This paper investigates the determinants of crop yield and profit of small family farms in Senegal using both a production and a profit function. The econometric analysis is based on information on agricultural inputs and outputs from 505 agricultural household members of a farmer organization in the Saint Louis region collected in 2009. The analysis of our results indicate that the development of commercialization sectors and agricultural loans would be required prior to increasing agricultural inputs. Our findings also suggest that information on planting technique, soil preparation and management of lands could allow productivity increases, but that an increase in the bargaining power of farmers is required to increase unit prices and consequently their profits.
\end{abstract}

Keywords: crop productivity; profit; family farms; Senegal 


\section{Introduction}

Agricultural intensification is a prerequisite for development and economic growth (Mellor 1976). Such intensification of agriculture is achieved by increasing productivity, cropping intensity and switching to high value crops (Boserup 1965, Pretty et al. 2001). While Senegal enjoyed several agricultural growth phases since its independence in 1960, the average production and productivity trend remained stationary (Kelly et al. 1996). As a result, Senegal relies heavily on imports to face the local food demand. For instance, because rice domestic production represents only $15 \%$ of the demand, Senegal has imported on average 880 thousand tons of rice annually since 2000 (Lancon and Benz 2002). This places Senegal as the second largest importer of rice in Sub-Saharan Africa. The heavy reliance of Senegal on imports for food supply leaves local population vulnerable to increased prices and volatility from international markets during crises. To address the food security issue, different policies have been implemented to promote national food production growth. In 2008, the Government of Senegal launched the Great Push Forward for Agriculture, Food, and Abundance (GOANA), which targets food self-sufficiency by 2015. This policy further supports a 2005 policy, the National Program of Self-sufficiency in Rice (PNAR), aiming to achieve a domestic paddy rice production of 1.5 million tons by 2012. However, Senegal is still far from achieving its goal of a $250 \%$ rice production increase per year (Diagne et al. 2013). In this regard, understanding the determinants of family farm crop yield and profits is essential in improving their viability and ultimately the Senegalese agricultural sector as a whole. This is the focus of the current paper.

Numerous studies have investigated the issue of farm productivity. Most of these studies consider agricultural productivity (e.g. Battese et al. 1996, Dorward 1999, Cornia 1985, Cabas et al. 2010, Sherlund et al. 2002). When considering Sub-Saharan Africa, agricultural productivity improvement has been the object of particular interest in the literature on economic development and poverty alleviation (Abdulai and Huffman 2000). Such studies have considered the effect on crop yields of weather (Blanc 2012, Schlenker and Lobell 2010), farm size (Cornia 1985, Byiringiro and Reardon 1996), gender and plot ownership (Goetghebuer 2011, Guirkinger and Platteau 2011, Kanzianga and Wahhaj 2010), environmental conditions (Sherlund et al. 2002), irrigation (Connor et al. 2008) or management practices (Kihanda et al. 2007, Subbarao et al. 2000, Poussin et al. 2003). Studies focusing on crop productivity along the Senegal river found that weed and $\mathrm{N}$ fertilizer management are major determinants of rice variability (Poussin et al. 
2003) and that $\mathrm{N}$ fertilizer application also influences rice quality (Wopereis-Pura et al. 2002). Cisse and Diallo (2007) find that groundnuts yields are impacted by environmental stress.

The use of production functions to determine farm productivity is restrictive, as it does not account for disparities in input and output prices across farms. An analysis of farm profits addresses this shortcoming by including the effect of price of agricultural inputs and outputs. In Sub-Saharan Africa, farm profits, driving agricultural growth, have gained more recent attention due to the implementation of agricultural and economic reforms. In a study of Nigeria, Ugwumba et al. (2010) find that farm cash income is influenced by household size, farmers' age, education, experience, type of integration and gender, and input costs. Reardon et al. (1997)'s synthesis of four case studies in Burkina Faso, Rwanda, Zimbabwe and Senegal, emphasizes the need for increased inputs, region specific strategies, off-farm employment opportunities and cash cropping programs. However, Abdulai and Huffman (2000) argue that studies considering the effect of market indicators and household characteristics on farm efficiency are scarcer.

This study focuses on the Saint Louis region, which plays an essential role in the Senegalese agricultural production: it produced 59\% of the national production in 2008 (Agence Nationale de la Statistiques et de la Demographie 2009). The population of the Saint Louis region relies traditionally on the production of one or two cash crops for income and several food crops for subsistence. This study considers the determinants of productivity and profit of the three most cultivated crops only: tomato, rice, and onion. The objective is ultimately to identify constraints to agricultural improvement which would require attention in development programs in order to improve the well-being of the populations.

We describe the study area in Section 2 and the survey data is described in Section 3. In Section 4, we present the methodology employed. The results of the analysis are presented in Section 5. Section 6 concludes.

\section{Data}

\subsection{Survey data}

The farm survey was conducted by Lépine (2009) in three rural communities of the Saint-Louis region in Senegal: Ross Béthio, Gaë and Guédé. These regions are located along the Senegal 
River, which forms the border between Senegal and Mauritania. This river is essential to agricultural production in these regions as it allows the practice of irrigation. Most of the 110,000 inhabitants of the three rural communities considered in the survey derive their livelihoods from farming. They generally cultivate rice, tomato and onion for income, and to a small extent for their own consumption, which is complemented with several other food crops (sweet potato, corn, mango, millet, eggplant, gumbo, bean, chili pepper). Some of them also have cattle.

The survey was carried out during May and June 2009 and targeted 505 rural households ${ }^{1}$ over 39 villages, as represented in Figure 1. These households were selected for their dependence on agriculture for livelihood and their membership to a farmer organization. These organizations represent important social structures in Senegal as they allow farmers to access and manage collective loans in order to finance their agricultural inputs. Their development may be attributable to market failures, rent-seeking and the presence of leadership (Arcan 2002). An exhaustive survey of farmer organizations located in the three rural communities was conducted and reported 482 farmer organizations with an average size of 79 members. Based on the size of each farmer organization, the Probability-Proportional-to-Size (PPS) method was used to sample 89 farmer organizations in the first stage, followed by the random selection of households in each farmer organization in the second stage.

All households surveyed are member of a famer organization and most of them (69\%) have received a collective agricultural loan from the Senegalese Agricultural Development Bank (CNCAS). Usually, the farmer organization will apply for a collective loan from the bank. The organization's president will then purchase the inputs depending on the needs of the members and redistribute them to every member. The farmer organization is collectively responsible for the loan and has to cover any individual default. The presence of the bank, which is necessary for most farmers, nevertheless generates negative externalities by reducing farmers' leeway. Indeed, farmers chose to produce tomatoes, as they are more likely to obtain a loan thanks to the presence of the marketing company Senegalese Canned Food Company (SOCAS), which ensures a stable and easily accessible outlet of production. This company collects the harvest and

\footnotetext{
${ }^{1}$ A household is defined as "a group of individuals who live and work on plot together, prepare meals together for home consumption and pool resources in order to provide for their essential needs". The members of the household recognize the authority of the head of the household. This definition corresponds to the notion of "Njël" in Wolof or "Hirande" in Foula, both notions includes the idea that the household is a consumption-production group.
} 
pays the farmer's organization at a fixed price of 55FCFA per kilo (0.11USD). This price is, however, well below the market price of 150FCFA. Additionally, this company has been criticized of deliberately collecting the harvest late so that the tomatoes have started losing water and weight - the appearance of the tomatoes being less of an issue for canning purposes. Farmers would therefore prefer to cultivate other crops, such as onion, which would be easier to grow, require less inputs and are easier to store than tomatoes. However, as there is no guaranteed outlet for other produces, farmers not supplying the SOCAS would not be eligible for loans from the CNCAS bank.

From the 505 farms surveyed, we obtained cropping information over three seasons: the rainy season, the warm and dry season, and the cold and dry season. The rainy season is characterized by a large rainfall and spans from June to October. The dry season, from October to March, is the coldest and has very low rainfall. The warm season, from March to June, is the warmest and also has very low rainfall. $35 \%$ of the crops are cultivated during the rainy season, $21 \%$ during the dry season, and $44 \%$ during the warm season.

Crop specific data regarding inputs, such as the quantity of seed used and their origin, the number of weeding, the quantity of fertilizer applied and its type, the quantity of insecticide, the benching technique and soil preparation technique employed, are collected for each plot and season. The survey also provided information on labor required and origin (family vs employed) to tend the fields and the output obtained (number of kilograms produced). Information on the retail price of the production and the cost of the inputs are used to calculate profit generated by farmers.

In Senegal, agricultural crops are cultivated on collective or private fields. Whether the plot was collective or private (variable priv) was assessed by the number of workers working on it. While the work is mainly conducted by men, women participate in the production of cash crops on collective fields. They also cultivate separate fields, which are usually very small and consist mainly of sweet potato and onion.

The list of variables of interest for this study is presented in Table 1. 


\subsection{Weather data}

Daily rainfall data were extracted from the RFE (version 2.0) dataset implemented by the National Oceanic and Atmospheric Administration (NOAA) - Climate Prediction Center (CPC). These data, which were generated from a combination of rain gauges and satellite observations, were available at FEWS NET Africa Data Portal at the 0.1 degree resolution $(\sim 10 \mathrm{~km}){ }^{2}$

Daily reference evapotranspiration (ETo $)^{3}$ data at the 1 degree resolution were extracted from the National Oceanic and Atmospheric Administration's Global Data Assimilation System (GDAS). Daily ETo represents the evaporative demand of the air and was calculated using the Penman-Monteith equation following the FAO methodology (Allen et al. 1998).

To obtain village specific weather data, we calculated the seasonal mean of gridded ET and rain within a radius of $3 \mathrm{~km}$ around each village.

\section{Methodology}

Crop yield determinants are investigated by estimating a production function. We assume that crop yields depend on a number of potential factors as follows:

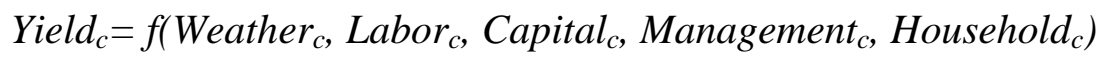

where for each crop $c$, the dependent variable Yield is measured as the production per area cultivated. Weather includes a measure of rainfall and evapotranspiration, Labor refers to the number of workers per hectare while Capital inputs include other agricultural inputs (land, the quantity of seed, fertilizer and insecticide) as well as the place where seed were bought and the type of fertilizer used. Management includes the type of benching technique and soil preparation technique employed as well as the number of weeding conducted. To account for household specificities, we introduced the Household control variables such as the composition of labor in the household (ratiodepwork), size (hsize), access to electricity (elec), household head age

\footnotetext{
${ }^{2}$ http://earlywarning.usgs.gov/fews/africa/index.php

3 Data are available at http://earlywarning.usgs.gov/fews/global/index.php. This source labels reference evapotranspiration 'potential evaporation'. However, as noted in R. G. Allen et al., "Crop evapotranspiration - Guidelines for computing crop water requirements," in FAO Irrigation and drainage paper (Rome: Food and Agricultural Organization, 1998)., "the use of other denominations such as potential ET is strongly discouraged due to ambiguities in their definitions."
} 
(hh_age), gender (hh_female) and education (hh_nbyrscol), and whether the household has access to credit facilities (credit_access).

Using a profit function, we can include the effect of the price of inputs and outputs. The profit function is specified as:

$$
\text { Profit }_{c}=f\left(\text { Yield }_{c}, \text { Price }_{c}, \text { Cost }_{c}\right)
$$

where for each crop $c$, Profit is measured as the total sale revenues minus all costs per area cultivated, Yield is the production per area cultivated, Price is the unit price of the output at the time of the sale and Cost is the unit cost of inputs.

In addition to the control variables listed above, the type of crop produced is included in the two equations. To account for time varying fixed effects, we use cropping season dummies: the rainy season (wintering), the warm and dry season (warm_season), and the cold and dry season (cold_season). We include rural district dummies in order to control for time invariant unobserved characteristics of the location.

The statistical analysis is performed with the statistical package Stata (StataCorp 2011). We estimate the regressions using the ordinary least squares technique. Since there are several households per village, the error term might not be independently and identically distributed. We thus calculate standard errors that are clustered by village in order to obtain a cluster-robust covariance matrix estimator.

To estimate the production and profit function, we follow the specific-to-general modelling strategy, where the first specification considers details explanatory variables (e.g. the quantity of fertilizer employed and the type of fertilizer). The second specification reduces the set of explanatory variable to limit the specification to general factors (e.g. the quantity of fertilizer employed only). This strategy is preferred in order to avoid potential correlation issues between explanatory variables.

\section{METHODOLOGICAL ISSUES}




\section{Results}

\subsection{Summary statistics}

Summary statistics for the surveyed households producing rice tomato and onion are detailed in Table 2. On average, a household consists of 9 individuals and there are about 2.3 dependent members per worker in the household. The household head are mainly male (91\%) and received an average of 2.3 of education. $65 \%$ of the households have access to electricity.

In the sample, each household cultivates 2.3 different plots. On each plot they can produce a single crop during different seasons and/or intercrop different crops during the same season. Some households may produce up to 3 different crops during the 3 different seasons and thus have 9 observations for each plot. Overall, $99 \%$ of the sampled households produce at least one crop, $66 \%$ produce two crops, and $40 \%$ produce three crops or more. The main cultivated crops are rice, tomato and onion, which are respectively produced by $88 \%, 50 \%$ and $42 \%$ of the households. $10 \%$ of the rice and tomato plots and $12 \%$ of the onion plots are cultivated privately, i.e., there is only one household member working on these fields. In the sample, we find that $10 \%$ of crops are private and $90 \%$ are collective fields. Among those cultivated privately, only $9 \%$ of rice plots, $4 \%$ of onion plots, and $8 \%$ of tomato plots are cultivated by women.

On average, three male and two female household members work on each cultivated crop and work on average 40 and 12 days, respectively. Family workforce represents about $80 \%$ of total labor. In contrast, permanent workers, who are hired for the whole year or the whole season and who live in the household, are not very common as they work on only $9 \%$ of the sections. Contracted workers, who are hired to carry out a specific task, such as ploughing, work on $11 \%$ of the sections. However, most of the sections require day workers, which are employed on 57\% of the sections. In each section, there are on average three day workers who each work on average three days, mainly during the harvest.

Crop statistics presented in Table 3 show that rice has the largest number of observations in the sample. It also occupied the largest crop plots with an average of $1.6 \mathrm{Ha}$, compared to $0.36 \mathrm{Ha}$ for tomato and $0.5 \mathrm{Ha}$ for onion. In terms of yields, the average for rice in the sample is $4,647 \mathrm{Kg} / \mathrm{Ha}$. In comparison, the national average of rice yields reported in 2009 by FAOSTAT 
(2013) is 3,600Kg/Ha. ${ }^{4}$ Yields of onion and tomato, which have a higher water content, average $10,660 \mathrm{Kg} / \mathrm{Ha}$ and $22,031 \mathrm{Kg} / \mathrm{Ha}$ respectively. These yields are lower than the national average of $25,000 \mathrm{Kg} / \mathrm{Ha}$ and $27,272 \mathrm{Kg} / \mathrm{Ha}$ (FAOSTAT 2013). Only $4 \%$ of the rice plots and $2 \%$ of onion and tomato plots are on average affected by a natural disaster (e.g., salinization, pests). Rice benefits from the largest rainfall (146mm per season on average) essentially because rice is grown during the wet season. The largest rate of ETo is however observed on tomato plots, which are mainly grown in the semi-desert region of Fouta ( $76 \%$ of the tomato plots are located in the Gaë and 23\% in Guédé areas). The ETo is also representative of the fact that $94 \%$ of the tomato plots were cultivated during the warm season. Tomato plots require the largest amount of labor (545 days of work). Only a small number of plots are cultivated by hired workers (12\% for onion and $11 \%$ for tomato and rice on average). Tomato receives the largest amount of fertilizer and insecticide per area cultivated $(998 \mathrm{Kg}$ and $7 \mathrm{Kg}$ respectively on average). The fertilizers used are mainly chemical (92\% for rice, $91 \%$ for onion and $90 \%$ for tomato). Rice, however, has the highest seed density, with $147 \mathrm{Kg} / \mathrm{Ha}$. The majority of the seeds are purchased $(94 \%$ for onion, $91 \%$ for tomato and $76 \%$ for rice). Mechanized planting is only used on $2 \%$ of the rice plots, $4 \%$ of the tomato plots, and $5 \%$ of the onion plots. Tomato plots require the largest amount of weeding ( 3 times during the warm and dry season). In terms of soil preparation, $96 \%$ of the rice fields are offseted ${ }^{5}$ and only $1 \%$ are bioned ${ }^{6}$, offseted and bioned or ploughed. Onion and tomato plots are mainly offseted and bioned (43\% and $83 \%$ respectively).

When considering prices, famers sell rice for $157 \mathrm{FCFA} / \mathrm{Kg}$ on average, while they only get 90FCFA/Kg for onions and $54 \mathrm{FCFA} / \mathrm{Kg}$ for tomatoes. However, profits per hectare are on average the largest for tomato with 599,394FCFA. Average profits per hectare for rice and onion are respectively 459,411FCFA and 432,103FCFA. The larger profit per hectare obtained for tomato is mostly explained by a selection issue as the best farmers are more likely to obtain a loan, which is mainly available to produce tomato due to the presence of a marketing company. The less performing and less risky farmers, i.e. those who did not obtain a loan produce onion, which can explain the low profit per hectare for onion crops.

\footnotetext{
${ }^{4}$ The production of straw from rice byproduct is not considered in the analysis.

${ }^{5}$ Offsetage refers to a technique of soil preparation widely used in Senegal and Mauritania consisting of disc ploughing offset from the tractor.

${ }^{6}$ Bionage refers to a technique of ploughing that consists in cutting the soil in lifted strips.
} 
When considering the average cost of agricultural inputs per hectare (water, seed, weeding, fertilizer, insecticide, and soil preparation), i.e., the total cost of inputs divided the by area of land cultivated, the highest expenses are for tomato (281,759FCFA) and the smallest for onion $(132,834 \mathrm{FCFA})$. The cost of hired labor is also on average the highest for tomato $(50,246 \mathrm{FCFA})$ and the smallest for onion (24,010FCFA).

\subsection{Production function}

Full results for the estimation of the production function are presented in Table 4 for the three main crops produced in the region. In order to simultaneously provide an indication of also their relative economic significance, we provide the standardized coefficients of all significant factors

in Table 5. One should note in this regard that the figures should be interpreted as the change in the dependent variable per standard deviation increase of the explanatory variable in question.

\subsubsection{Rice}

The first thing one may notice is that none of the weather variables are significant determinants of the production functions of rice. This may not be surprising given that crops in the study area are all irrigated, therefore less sensitive to weather. There are, however, a number of other determinants that have a significant effect on the production of rice. We find that the amount of land cultivated is negatively associated with rice yields. Looking at the size of the impact one finds that an increase in one standard deviation of the land area reduces yields by 0.207 standard deviations.

In terms of fertilizer, the quantity employed has no significant impact on rice yields. However, the use of the chemical type increases rice yields by 0.081 standard deviations. We additionally find that weeding during season has a negative impact for rice. The event of an agricultural shock explains decreasing rice yields. Other household characteristics, such as the gender and education of the head, whether the field is private and the size and composition of the household, have no significant effect on rice yields.

Reporting the standardized coefficients allows us to assess how the significant factors matter relative to other determinants and across the three crop types. In this regard, the most significant 
factor for rice is the amount of land cultivated with the biggest, but negative, standardized coefficient. Access to credit also has a relatively large importance for rice yields.

To tests the sensitivity of our results to alternative specifications, we added additional regressions considering a simpler set of determinants (i.e., we included soilprep combining all types of soil preparation into a single category; we removed the com_seed and fert_chem variables). The results showed similar levels of significance and quantitative effects of the explanatory variables, except for fert_chem, which appears to change the significance of qfertiliser for onion and tomato.

\subsubsection{Onion}

As for rice, rain and ETo do not have a significant effect on onion yields. Cultivated area is also negatively associated with onion yields. The standardized coefficients show that cultivated area is the most important factor for onion yields. An increase in one standard deviation of the land area reduces yields by 0.38 standard deviations.

The standardized coefficients also show that the use of chemical fertilizers has the second largest impacts, although still only about half of the impact of land cultivated. For this crop, the use of the chemical type reduces onion yields by 0.216 standard deviations. However, when considering the reduced specification, which does not consider the type of fertilizer employed, the quantity employed per hectare has a now a slightly significant impact on onion yields. Our results also show that the number of seeds used per hectare significantly impacts onion yields. In contrast, seed origin appears not to play a role for onion production.

\subsubsection{Tomato}

The regression results for tomato establish no significant relationship between weather and yields. Also, similarly to the two other crops, the area cultivated is a significant determinant of yields. The quantity of seed used per hectare of land cultivated does not have a significant effect

in this sample, but the origin of the seeds does. The use of seeds bought on the market results in lower tomato yields than when using the use of farmers' own seeds. 
The amount of fertilizer and access to credit, which is used to purchase fertilizers and other inputs, are also relatively important factors for tomato yields. Regarding benching techniques, it appears that relative to the inline technique, only pricking has a lower effect for tomato, reducing its yields by 0.122 standard deviations. Also for tomato, relative to offstage, manual ploughing reduces yields by 0.124 standard deviations. As for rice, the number of weeding has a negative impact on tomato yields. Finally, farmer's access to electricity is associated with higher tomato yields, increasing it by 0.262 standard deviations.

\subsection{Profit function}

Results for the crop-specific profit function regressions are presented for both sets of regression in

\begin{tabular}{|c|c|c|c|c|c|c|}
\hline \multirow[t]{2}{*}{ Variabl } & \multicolumn{2}{|c|}{ Rice } & \multicolumn{2}{|c|}{ Onion } & \multicolumn{2}{|c|}{ Tomato } \\
\hline & (1) & (2) & (1) & (2) & (1) & (2) \\
\hline larea & $\begin{array}{c}- \\
(0.207)\end{array}$ & $\begin{array}{c}- \\
(0.226)\end{array}$ & $\begin{array}{c}- \\
(0.380)\end{array}$ & $\begin{array}{c}- \\
(0.418)\end{array}$ & $\begin{array}{c}- \\
(0.255)\end{array}$ & $\begin{array}{c}- \\
(0.235)\end{array}$ \\
\hline qseedha & & & $\begin{array}{c}- \\
(0.140)\end{array}$ & $\begin{array}{c}- \\
(0.150)\end{array}$ & & \\
\hline com_seed & & & & & $\begin{array}{c}- \\
(0.140)\end{array}$ & \\
\hline fert_chem & $\begin{array}{c}+ \\
(0.081)\end{array}$ & & $\begin{array}{c}- \\
(0.216)\end{array}$ & & & \\
\hline qfertiliserha & & & & $\begin{array}{c}+ \\
(0.248)\end{array}$ & $\begin{array}{c}+ \\
(0.171)\end{array}$ & \\
\hline pricking & & & & & $\begin{array}{c}- \\
(0.122)\end{array}$ & \\
\hline qweeding & $\begin{array}{c}- \\
(0.049)\end{array}$ & $\begin{array}{c}- \\
(0.045)\end{array}$ & & & $\begin{array}{c}- \\
(0.103)\end{array}$ & $\begin{array}{c}- \\
(0.105)\end{array}$ \\
\hline chocagri & $\begin{array}{c}- \\
(0.106)\end{array}$ & & & & & \\
\hline elec & & & & $\begin{array}{c}+ \\
(0.237)\end{array}$ & $\begin{array}{c}+ \\
(0.262)\end{array}$ & $\begin{array}{c}- \\
(0.002)\end{array}$ \\
\hline hh_age & & & & & & $\begin{array}{c}\mathbf{+} \\
(8.234)\end{array}$ \\
\hline credit_access & $\begin{array}{c}+ \\
(0.150)\end{array}$ & $\begin{array}{c}- \\
(0.078)\end{array}$ & & & $\begin{array}{c}+ \\
(0.153)\end{array}$ & \\
\hline
\end{tabular}

Note: The - and + signs represent the effect of coefficients for the significant variables only; Standardized coefficients are provided in parenthesis in absolute value. 
Table 6. The corresponding standardized coefficients are provided in Table 7.

\subsubsection{Rice}

Crop yield is the most important explanatory factor of profit for rice farmers. A one standard deviation change in rice yield increases profit per hectare by 0.79 standard deviations. While the effect of prices is substantially lower, a one standard deviation increase in price still raises per hectare profits by 0.542 standard deviations.

In terms of unit costs, we find that for rice it is only the cost of hired labor that matters, although not to any great quantitative extent. As a sensitivity analysis, we considered UC_total, which represents the total unit cost of inputs as an alternative to detailed unit costs. The alternative specification, however, does not change qualitatively the results and demonstrates a considerable degree of robustness of the analysis.

\subsubsection{Onion}

Yields and retail price of onion are also the main determinant of onion profit per hectare. For this crop, however, the unit cost of seeds and insecticides both reduce profits, where their impact is not too different from each other. In contrast, the cost of fertilizer works to increase profits, although in absolute value its effect is about half that of seeds and insecticide.

The results from the reduced specification (considering total unit costs instead of detailed unit costs) indicate that unit cost increases entail, as expected, a decrease in profit per hectare. However, this summary variable is only significant for onion.

\subsubsection{Tomato}

For tomato, a one standard deviation change in crop yields increases profits by 0.92 standard deviations. While the effect of prices is substantially lower, a one standard deviation increase in

price still will raise per hectare profits by 0.542 standard deviations. In terms of unit costs, only the cost of seeds matters, where a one standard deviation rise reduces profits by 0.042 standard 
deviations. Accordingly, the alternative specification shows no significant effect of total unit costs on profit for tomato farmers.

\section{Discussions}

The most important determinant of crop yields is the area cultivated. The negative relationship between the amount of land cultivated and agricultural yields may be due to the fact that family farms, contrary to agribusinesses, experience diseconomies of scale when cultivated area increases. Households may experience management issues when cultivating larger plots. This result is consistent with the findings of Cornia (1985) and may be explained by the fact that the share of fixed in total cost of family farms is determined by the low use of equipment.

Regarding weeding, the negative influence of the amount of weeding on crop yields is surprising and could indicate endogeneity issues as plots prone to weed invasions would require a greater amount of weeding and, in case where the care is not commensurate with the weed invasion, could result in lower yields.

Access to credit has a substantial importance for tomato production, for which household are eligible for loans through the farmer organization. Surprisingly, a relatively more important effect of the same factor is estimated for rice despite not qualifying farmers for loans. However, this effect can be explained by the fact that tomato growers use part of the inputs for other crops. This result shows that the presence of a cooperative has incidental beneficial effects on crops other than the targeted ones.

The regression results show that a better utilization of inputs, such as fertilizers, can help increase productivity. Intensification of agricultural production is necessary in a country such as Senegal to ensure sufficient food availability for local populations. However, intensification entails sustainability issues such as soil degradation, water overuse, fertilizer and pesticide pollution.

As expected, the profit function shows that price and crop yields are significant and are the most important determinants of profits per hectare for all three crops. Unit costs are slightly less important and differ widely depending on the crop type considered. 
Irrigation schemes in the Senegal river valley also play an important role for crop yields and the economic prosperity of the villages (Connor et al. 2008, Mateos et al. 2010, Comas et al. 2012, García-Ponce et al. 2013, Borgia et al. 2013). In the sample surveyed, all farmers had access to irrigation for their crops, so this determinant is not included in the regression analysis.

\section{Conclusions and policy implications}

Using a sample of family farms for 2009 we have examined the determinants of yields and profits for three main crops produced in the Saint Luis region in Senegal. Our regression analysis has unearthed a number of findings that could help development of the agricultural sector in this region. In this regard, there are a number of factors that are consistently important determinants of yields of all crops. For instance, we find that the size of the cultivated area acts to reduce yields, suggesting potential diseconomies of scale. This might suggest that further improvements in management and organization might be able to allow farmers to be more productive even when they are managing large areas. We also find that the development of commercialization sectors and loans could boost agricultural inputs. Our findings additionally suggest that information on planting technique, soil preparation and management of lands could improve crop yields. However, the main agricultural inputs (insecticide, fertilizer, labor) are found to have a low effect on crop yields. This is probably explained by the fact that farms extensively using these inputs may be self-selected in the sense that they may have lower yields than the average farm. Despite these general patterns, we also found that many factors appear not to be important, or if they are, their effects are heterogeneous across crop types. For instance, while access to credit seems to matter for rice and tomato production, it has no effect on onion yields. Thus our results suggest that while eradicating imperfections in the credit system can aid some crops, for others this may not be part of the solution to greater production.

In terms of profitability, our results show that yields and prices play significant and important roles for all three crops. Thus, as demonstrated earlier, while it is important to understand the main determinants of yields, it is also important to increase the bargaining power of farmers in order to increase the price of the sale. 
This study's results indicate that several policies could be effective in order to reach selfsufficiency in Senegal. First, market imperfections such as the weakness of the credit system and the breakdown of agricultural inputs supply act as barriers to self-sufficiency (de Mey et al., 2012). In fact, policies allowing increased access to loans to buy agricultural inputs will have a positive effect on yields. Additionally, the monopoly of the commercialization sector for tomato (SOCAS) distorts incentives and prevent farms from reaching pareto-optimality regarding the type of crop that should be produced. More importantly, the absence of several commercialization sector results in a very low bargaining power of farmers who are price takers. Farmers should also try to sell off their output on other markets, such as on the Saint Louis, Podor Richard toll and Dakar markets. This may require a better organization of farmers but could be possible thanks to the use of Information and Communication Technologies (ICT). ICT are needed in the current context of asymmetric information in order to prevent traders to exploit farmers' ignorance of the market price (Courtois and Subervie 2013, Munyua et al. 2009). Finally, the salinization of agricultural lands is an issue for many villages of the Ross Béthio rural community. Other covariant risks affecting the area, such as bird damages have a strong negative effect on plots yields and profit. Insurance schemes should be developed in order to protect households from experiencing a loss of the production. Further research is needed to investigate the effectiveness of the introduction of agricultural insurance.

\section{References}

Abdulai, Awudu, and Wallace Huffman. "Structural Adjustment and Economic Efficiency of Rice Farmers in Northern Ghana." Economic Development and Cultural Change 48, no. 3 (2000): 503-20.

Agence Nationale de la Statistiques et de la Demographie. "Situation Économique Et Sociale De La Région De Saint Louis De 2008." Dakar: Ministère de l'Economie et des Finances, 2009.

Allen, R. G., L. S. Pereira, D. Raes, and M. Smith. "Crop Evapotranspiration - Guidelines for Computing Crop Water Requirements." In FAO Irrigation and drainage paper Rome: Food and Agricultural Organization, 1998.

Arcan, J.L. "Producer Organizations in Burkina Faso and Sénégal: A Synthesis of Case Studies in Twenty Villages." In Mimeo, 2002.

Battese, George E., Sohail J. Malik, and Manzoor A. Gill. "An Investigation of Technical Inefficiencies of Production of Wheat Farmers in Four Districts of Pakistan." Journal of Agricultural Economics 47, no. 1-4 (1996): 37-49. 
Blanc, Élodie. "The Impact of Climate Change on Crop Yields in Sub-Saharan Africa." American Journal of Climate Change 1, no. 1 (2012): 1-13.

Borgia, Cecilia, Mariana García-Bolaños, Tao Li, Helena Gómez-Macpherson, Jordi Comas, David Connor, and Luciano Mateos. "Benchmarking for Performance Assessment of Small and Large Irrigation Schemes Along the Senegal Valley in Mauritania." Agricultural Water Management 121, no. 0 (2013): 19-26.

Boserup, E. The Conditions of Agricultural Growth: Economics of Agrarian Change under Population Pressure. London: Allen and Unwin, 1965.

Byiringiro, Fidele, and Thomas Reardon. "Farm Productivity in Rwanda: Effects of Farm Size, Erosion, and Soil Conservation Investments." Agricultural Economics 15, no. 2 (1996): 127-36.

Cabas, Juan, Alfons Weersink, and Edward Olale. "Crop Yield Response to Economic, Site and Climatic Variables." [In English]. Climatic Change 101, no. 3-4 (2010/08/01 2010): 599616.

Cisse, Madiama, and Souleymane Diallo. "Evaluating Performance and Yield Stability of Some Groundnut (Arachis Hypogaea L.) Varieties under Irrigation in Three Agroecological Zones of the Senegal River Valley." Chap. 66 In Advances in Integrated Soil Fertility Management in Sub-Saharan Africa: Challenges and Opportunities, edited by Andre Bationo, Boaz Waswa, Job Kihara and Joseph Kimetu. 713-22: Springer Netherlands, 2007.

Comas, Jordi, David Connor, Mohamed El Moctar Isselmou, Luciano Mateos, and Helena Gómez-Macpherson. "Why Has Small-Scale Irrigation Not Responded to Expectations with Traditional Subsistence Farmers Along the Senegal River in Mauritania?". Agricultural Systems 110, no. 0 (2012): 152-61.

Connor, David, Jordi Comas, Helena-Gómez Macpherson, and Luciano Mateos. "Impact of Small-Holder Irrigation on the Agricultural Production, Food Supply and Economic Prosperity of a Representative Village Beside the Senegal River, Mauritania." Agricultural Systems 96, no. 1-3 (2008): 1-15.

Cornia, Giovanni Andrea. "Farm Size, Land Yields and the Agricultural Production Function: An Analysis for Fifteen Developing Countries." World Development 13, no. 4 (1985): 513-34.

Courtois, Pierre, and Julie Subervie. "Farmer Bargaining Power and Market Information Services." Paper presented at the CSAE Conference 2013: Economic Development in Africa, St Catherine's College, Oxford, 2013.

de Mey, Yann, Matty Demont, and Mandiaye Diagne. "Estimating Bird Damage to Rice in Africa: Evidence from the Senegal River Valley." Journal of Agricultural Economics 63, no. 1 (2012): 1477-9552.

Diagne, Mandiaye, Matty Demont, Papa Abdoulaye Seck, and Adama Diaw. "Self-Sufficiency Policy and Irrigated Rice Productivity in the Senegal River Valley." Food security 5, no. 1 (2013): 55-68.

Dorward, Andrew. "Farm Size and Productivity in Malawian Smallholder Agriculture." The Journal of Development Studies 35, no. 5 (1999/06/01 1999): 141-61.

FAOSTAT. "Fao Statistical Databases." http://faostat.fao.org, 2013.

García-Ponce, E., H. Gómez-Macpherson, O. Diallo, M. Djibril, C. Baba, O. Porcel, B. Mathieu, et al. "Contribution of Sorghum to Productivity of Small-Holder Irrigation Schemes: On- 
Farm Research in the Senegal River Valley, Mauritania." Agricultural Systems 115, no. 0 (2013): 72-82.

Goetghebuer, Tatiana "Productive Inefficiency in Patriarchal Family Farms: Evidence from Mali." Paper presented at the German Development Economics Conference, Berlin, 2011.

Guirkinger, C. , and J.P. Platteau. "The Effect of Land Scarcity on Farm Structure: Empirical Evidence." In CRED working paper. Belgium: Center for Research in DevelopmentEconomics, University of Namur, 2011.

Kanzianga, H., and Z. Wahhaj. "Gender, Socila Norms and Household Production in Burkina Faso." In Mimeo, 2010.

Kelly, V., B. Diagana, T. Reardon, M. Gaye, and E. Crawford. "Cash Crop and Foodgrain Productivity in Senegal: Historical View, New Survey Evidence, and Policy Implications." In Food Security International Development Papers 54051: Michigan State University, 1996.

Kihanda, F. M., G. P. Warren, and A. N. Micheni. "Effects of Manure Application on Crop Yield and Soil Chemical Properties in a Long-Term Field Trial in Semi-Arid Kenya." Chap. 44 In Advances in Integrated Soil Fertility Management in Sub-Saharan Africa: Challenges and Opportunities, edited by Andre Bationo, Boaz Waswa, Job Kihara and Joseph Kimetu. 471-86: Springer Netherlands, 2007.

Lancon, F., and David H. Benz. "Rice Imports in West Africa: Trade Regimes and Food Policy Formulation." In Mimeo, 2002.

Lépine, Aurélia. "Rural Household Survey." Senegal (SN2009), 2009.

Mateos, Luciano, David Lozano, Ahmed Baba Ould Baghil, Oumar Abdoul Diallo, Helena Gómez-Macpherson, Jordi Comas, and David Connor. "Irrigation Performance before and after Rehabilitation of a Representative, Small Irrigation Scheme Besides the Senegal River, Mauritania." Agricultural Water Management 97, no. 6 (2010): 901-09.

Mellor, J. W. The New Economics of Growth: A Strategy for India and the Developing World. Ithaca, NY: The Cornell University Press, 1976.

Munyua, Hilda, Edith Adera, and Mike Jensen. "Emerging Icts and Their Potential in Revitalizing Small Scale Agriculture in Africa." Paper presented at the IAALD AFITA WCCA, 2008 World Conference on Agricultural Information and IT, 2009.

Poussin, J. C., M. C. S. Wopereis, D. Debouzie, and J. L. Maeght. "Determinants of Irrigated Rice Yield in the Senegal River Valley." European Journal of Agronomy 19, no. 2 (2003): 341-56.

Pretty, Jules N. , Camilla Toulmin, and Stella B. Williams. Sustainable Intensification: Increasing Productivity in African Food and Agricultural Systems. Routledge, 2001.

Reardon, Thomas, Valerie Kelly, Eric Crawford, Thomas Jayne, Kimseyinga Savadogo, and Daniel Clay. "Determinants of Farm Productivity in Africa:A Synthesis of Four Case Studies." In SD Publication Series, Technical Paper No. 75: Michigan State University, 1997.

Schlenker, Wolfram, and David B Lobell. "Robust Negative Impacts of Climate Change on African Agriculture ". Environmental Research Letters 5 (2010): 1-8.

Sherlund, Shane M., Christopher B. Barrett, and Akinwumi A. Adesina. "Smallholder Technical Efficiency Controlling for Environmental Production Conditions." Journal of Development Economics 69, no. 1 (2002): 85-101.

StataCorp. "Stata Statistical Software: Release 12." College Station, TX: StataCorp LP, 2011. 
Subbarao, g. V., c. Renard, w. A. Payne, and a. Bationo. "Long-Term Effects of Tillage, Phosphorus Fertilization and Crop Rotation on Pearl Millet-Cowpea Productivity in the West-African Sahel." Experimental Agriculture 36, no. 02 (2000): 243-64.

Ugwumba, C.O.A., R.N. Okoh, P.C. Ike, E.L.C. Nnabuife, and E.C. Orji. "Integrated Farming System and Its Effect on Farm Cash Income in Awka South Agricultural Zone of Anambra State, Nigeria." American-Eurasian Journal of Agricultural \& Environmental Sciences 8, no. 1 (2010): 01-06.

Wopereis-Pura, M. M., H. Watanabe, J. Moreira, and M. C. S. Wopereis. "Effect of Late Nitrogen Application on Rice Yield, Grain Quality and Profitability in the Senegal River Valley." European Journal of Agronomy 17, no. 3 (2002): 191-98. 


\section{Tables}

Table 1. Variables description

\begin{tabular}{|c|c|c|}
\hline Variables & Descriptions & Unit \\
\hline \multicolumn{3}{|l|}{ Cropping } \\
\hline qty & Quantity of crop output & $\mathrm{Kg}$ \\
\hline area & Area cultivated & $\mathrm{Ha}$ \\
\hline yield & Crop yields & $\mathrm{Kg} / \mathrm{Ha}$ \\
\hline price & Unit price of crop output & $\mathrm{FCFA} / \mathrm{Kg}$ \\
\hline profitha & Profit per area cultivated & $\mathrm{FCFA} / \mathrm{Ha}$ \\
\hline chocagri & Agricultural shock, e.g. Salinization, pests: $1=y e s, 0=$ no & Dummy \\
\hline \multicolumn{3}{|l|}{ Household } \\
\hline elec & Family has electricity: $1=y e s, 0=$ no & Dummy \\
\hline hsize & Household size & Number \\
\hline hh_age & Age of the household head & Year \\
\hline hh_female & Female household head: $1=$ female, $0=$ male & Dummy \\
\hline ratiodepwork & Ratio of dependents to workers in the household & Number \\
\hline hh_nbyrscol & Household head education & Year \\
\hline credit_access & Household has access to credit: $1=$ yes, $0=$ no & Dummy \\
\hline priv & Individual plot: $1=y e s, 0=$ no & Dummy \\
\hline \multicolumn{3}{|l|}{ Weather } \\
\hline rain & Total rainfall & $\mathrm{Mm}$ \\
\hline ETo & Average potential evapotranspiration & Mm/day \\
\hline \multicolumn{3}{|l|}{ Labor } \\
\hline qalllabourha & Quantity of total family and hired labor per area cultivated & Days/Ha \\
\hline allhiredlabourdum & All hired labor dummy: $1=$ yes, i.e. no family labor, $0=$ no & Dummy \\
\hline \multicolumn{3}{|c|}{ Capital } \\
\hline qfertiliserha & Quantity of fertilizer used per area cultivated & $\mathrm{Kg} / \mathrm{Ha}$ \\
\hline fert_chem & Fertilizer type: $1=$ chemical, $0=$ other & Dummy \\
\hline qinsecticideha & Quantity of insecticide used per area cultivated & $\mathrm{Kg} / \mathrm{Ha}$ \\
\hline qseedha & Quantity of seeds used per area cultivated & $\mathrm{Kg} / \mathrm{Ha}$ \\
\hline com_seed & Seed origin: $1=$ commercial (shop or market), $0=$ other (e.g. donation) & Dummy \\
\hline \multicolumn{3}{|l|}{ Management } \\
\hline inline & Bench technique: $1=$ inline, $0=$ other & Dummy \\
\hline broadcast & Bench technique: $1=$ broadcast, $0=$ other & Dummy \\
\hline bunch & Bench technique: $1=$ bunch, $0=$ other & Dummy \\
\hline pricking & Bench technique: $1=$ pricking, $0=$ other & Dummy \\
\hline qweeding & Weeding during season & Number \\
\hline weeding_chem & Weeding technique: $1=$ chemical, $0=$ other weeding & Dummy \\
\hline offsetage & Soil preparation technique: $1=$ offsetage only, $0=$ other & Dummy \\
\hline bionage & Soil preparation technique: $1=$ bionage only, $0=$ other & Dummy \\
\hline offsetage_bionage & Soil preparation technique: $1=$ offsetage and bionage only, $0=$ other & Dummy \\
\hline manual_ploughing & Soil preparation technique: $1=$ ploughing only, $0=$ other & Dummy \\
\hline no_soilprep & Soil preparation technique: $1=$ none, $0=$ other & Dummy \\
\hline \multicolumn{3}{|c|}{ - } \\
\hline cinput & Total cost of inputs (seed, soil preparation, fertilizer, insecticide, weeding, water) & FCFA \\
\hline clabour & Total cost of all hired labor (day workers, contracted workers, permanent workers) & FCFA \\
\hline$U C_{-}$seed & Unit cost of seed & FCFA \\
\hline UC_fertiliser & Unit cost of fertilizer & FCFA \\
\hline UC insecticide & Unit cost of insecticide & FCFA \\
\hline UC_weeding & Unit cost of weeding & FCFA \\
\hline UC_hiredlabour & Unit cost of hired labor & FCFA \\
\hline
\end{tabular}


Table 2. Summary statistics for all crops

\begin{tabular}{|c|c|c|c|c|c|}
\hline Variables & Obs & Mean & Std dev & Min & Max \\
\hline qty & 1134 & 5371.737 & 8975.701 & 0 & 144000 \\
\hline area & 1157 & 0.767387 & 1.554794 & 0.02 & 32 \\
\hline yield & 1133 & 9613.715 & 10931.97 & 0 & 103333.3 \\
\hline price & 1156 & 126.0859 & 126.7301 & 0 & 2000 \\
\hline profitha & 1047 & 469502.5 & 717309.3 & -1350846 & 4231667 \\
\hline chocagri & 1158 & 0.031952 & & 0 & 1 \\
\hline elec & 1158 & 0.648532 & & 0 & 1 \\
\hline hsize & 1158 & 9.069084 & 3.854582 & 1 & 19 \\
\hline hh_age & 1158 & 50.11341 & 12.24024 & 18 & 89 \\
\hline hh_female & 1158 & 0.093264 & & 0 & 1 \\
\hline hh_nbyrscol & 1158 & 2.338515 & 3.808432 & 0 & 14 \\
\hline credit_access & 1153 & 0.741544 & & 0 & 1 \\
\hline priv & 1082 & 0.100739 & & 0 & 1 \\
\hline rain & 1158 & 84.06985 & 95.3977 & 2 & 274.9738 \\
\hline ETo & 1158 & 7.782967 & 1.161768 & 5.573022 & 9.081065 \\
\hline qalllabourha & 1138 & 489.7275 & 1079.073 & 0 & 17294.12 \\
\hline allhiredlabourdum & 1157 & 0.109767 & & 0 & 1 \\
\hline ratiodepwork & 1093 & 2.567081 & 2.183242 & 0 & 12 \\
\hline qfertiliserha & 1139 & 607.1498 & 711.1653 & 0 & 13333.33 \\
\hline qinsecticideha & 1072 & 3.971815 & 5.807566 & 0 & 70 \\
\hline qseedha & 1095 & 108.8589 & 331.6306 & 0 & 5000 \\
\hline com_seed & 1158 & 0.824698 & & 0 & 1 \\
\hline fert_chem & 1158 & 0.893782 & & 0 & 1 \\
\hline inline & 1150 & 0.066957 & & 0 & 1 \\
\hline broadcast & 1150 & 0.336522 & & 0 & 1 \\
\hline bunch & 1150 & 0.049565 & & 0 & 1 \\
\hline pricking & 1150 & 0.546957 & & 0 & 1 \\
\hline qweeding & 1093 & 1.997255 & 2.839251 & 0 & 30 \\
\hline weeding_chem & 1147 & 0.654752 & & 0 & 1 \\
\hline offsetage & 1133 & 0.578994 & & 0 & 1 \\
\hline bionage & 1133 & 0.07414 & & 0 & 1 \\
\hline offsetage_bionage & 1133 & 0.301854 & & 0 & 1 \\
\hline manual_ploughing & 1133 & 0.036187 & & 0 & 1 \\
\hline no_soilprep & 1133 & 0.008826 & & 0 & 1 \\
\hline cinput & 1085 & 210032.3 & 309754.9 & 1700 & 6276542 \\
\hline clabour & 1135 & 34345.9 & 101731.5 & 0 & 2160000 \\
\hline UC_seed & 1083 & 142753.5 & 499325.7 & 0 & $1.00 \mathrm{E}+07$ \\
\hline UC_fertiliser & 1139 & 518.1595 & 4111.935 & 0 & 128150 \\
\hline UC_insecticide & 1061 & 4402.749 & 9109.521 & 0 & 120000 \\
\hline UC_weeding & 1088 & 11408.41 & 35319.48 & 0 & 832000 \\
\hline UC_hiredlabour & 1135 & 1389.635 & 1773.23 & 0 & 24000 \\
\hline
\end{tabular}

Table 3. Crop specific summary statistics

\begin{tabular}{lccccccc}
\hline Crop & Obs & Statistic & qty & area & yield & price & profitha \\
\hline \multirow{2}{*}{ rice } & \multirow{2}{*}{575} & Mean & 4,294 & 1.1 & 4,647 & 157.4 & 459,411 \\
& & Std Dev & 9,344 & 2.1 & 3,198 & 81.0 & 577,084 \\
& & Min & 0 & 0.06 & 0 & 0 & $-972,169$ \\
& & Max & 144,000 & 32 & 22,857 & 500 & $4,231,667$ \\
onion & & Mean & 3,338 & 0.4 & 10,660 & 89.6 & 432,103 \\
& \multirow{2}{*}{209} & Std Dev & 4,344 & 0.4 & 8,626 & 27.3 & 808,325 \\
& & Min & 0 & 0.04 & 0 & 0 & $-1,078,330$ \\
& & Max & 33,600 & 2.08 & 50,000 & 200 & $3,651,111$ \\
tomato & & Mean & 10,955 & 0.5 & 22,031 & 54.3 & 599,394 \\
& \multirow{2}{*}{255} & Std Dev & 10,155 & 0.4 & 14,871 & 14.8 & 841,488 \\
& & Min & 0 & 0.04 & 0 & 0 & $-900,200$ \\
& & Max & 60,000 & 2.25 & 103,333 & 160 & $4,085,000$ \\
\hline
\end{tabular}


Table 4. Production function results using OLS (dependent variable: yield)

\begin{tabular}{|c|c|c|c|c|c|c|c|c|c|c|c|c|}
\hline \multirow{3}{*}{ Variables } & \multicolumn{4}{|c|}{ Rice } & \multicolumn{4}{|c|}{ Onion } & \multicolumn{4}{|c|}{ Tomato } \\
\hline & \multicolumn{2}{|c|}{ (1) } & \multicolumn{2}{|c|}{$(2)$} & \multicolumn{2}{|c|}{ (1) } & \multicolumn{2}{|c|}{ (2) } & \multicolumn{2}{|c|}{ (1) } & \multicolumn{2}{|c|}{ (2) } \\
\hline & Coeff & SE & Coeff & SE & Coeff & SE & Coeff & SE & Coeff & SE & Coeff & SE \\
\hline rain & -3.923 & $(12.40)$ & -4.467 & $(12.24)$ & -18.61 & $(273.5)$ & -22.64 & $(261.9)$ & 80.46 & $(1,293)$ & -44.54 & $(1,141)$ \\
\hline ETo & -179.5 & $(1,107)$ & -323.4 & $(1,091)$ & $-3,472$ & $(3,995)$ & $-4,204$ & $(4,209)$ & $-12,679$ & $(17,148)$ & $-11,782$ & $(14,735)$ \\
\hline qalllabourha & -0.0940 & $(0.325)$ & -0.167 & $(0.295)$ & -0.245 & $(0.711)$ & -0.511 & $(0.613)$ & -1.573 & $(2.099)$ & 0.403 & $(1.983)$ \\
\hline allhiredlabourdum & 637.6 & $(756.6)$ & & & 2,389 & $(3,081)$ & & & 115.9 & $(8,726)$ & & \\
\hline larea & $-782.3^{* * *}$ & $(232.5)$ & $-856.4^{* * *}$ & (233.6) & $-4,398^{* * *}$ & $(1,103)$ & $-4,842^{* * *}$ & $(1,098)$ & $-5,018^{* *}$ & $(2,513)$ & $-4,627^{* *}$ & $(2,266)$ \\
\hline qseedha & 1.665 & (1.312) & 1.658 & (1.248) & $-2.566^{* * * *}$ & $(0.634)$ & $-2.742^{* * * *}$ & $(0.650)$ & 1.479 & (9.808) & 3.616 & $(9.095)$ \\
\hline com_seed & 196.2 & (387.7) & & & 1,122 & $(5,308)$ & & & $-6,080^{* *}$ & $(2,949)$ & & \\
\hline qfertiliserha & -0.0740 & $(0.441)$ & -0.0788 & $(0.439)$ & 1.995 & $(1.236)$ & $1.950^{*}$ & $(1.102)$ & $4.796^{*}$ & $(2.531)$ & 3.992 & $(2.490)$ \\
\hline fert_chem & $1,038^{* *}$ & $(504.9)$ & & & $-8,154^{* *}$ & $(4,045)$ & & & $-2,504$ & $(5,655)$ & & \\
\hline qinsecticideha & 82.52 & $(63.58)$ & 78.57 & $(59.25)$ & -31.17 & (99.49) & -19.29 & (99.33) & 90.24 & (203.0) & 54.74 & (198.2) \\
\hline broadcast & 451.3 & (659.0) & & & 3,840 & $(5,938)$ & & & $-12,681$ & $(11,056)$ & & \\
\hline bunch & -656.4 & (926.2) & & & $-8,339$ & $(5,403)$ & & & $-16,197^{* *}$ & $(8,096)$ & & \\
\hline pricking & 1,264 & (798.0) & & & $-1,400$ & $(4,238)$ & & & $-4,523$ & $(6,305)$ & & \\
\hline qweeding & $-111.1^{*}$ & (61.13) & $-102.6^{*}$ & $(60.89)$ & -13.36 & $(258.0)$ & -45.13 & $(254.4)$ & $-392.1^{*}$ & $(228.5)$ & $-398.9^{*}$ & $(206.6)$ \\
\hline bionage & 1,125 & (949.8) & & & 174.4 & $(3,445)$ & & & $-5,364$ & $(12,614)$ & & \\
\hline offsetage_bionage & 2,817 & $(2,865)$ & & & -587.2 & $(2,780)$ & & & $-9,369$ & $(13,487)$ & & \\
\hline manual_ploughing & -325.5 & $(1,173)$ & & & $-1,555$ & $(3,710)$ & & & $24,736^{*}$ & $(13,198)$ & & \\
\hline no_soilprep & & & & & $-7,215$ & $(11,962)$ & & & & & & \\
\hline soilprep & & & & & & & 6,759 & $(10,542)$ & & & & \\
\hline chocagri & $-2,249^{*}$ & $(1,346)$ & $-2,204^{*}$ & $(1,219)$ & $-7,450$ & $(4,655)$ & $-4,387$ & $(3,192)$ & -655.6 & $(10,725)$ & -21.68 & $(9,621)$ \\
\hline ratiodepwork & 57.42 & $(62.56)$ & 46.36 & (58.93) & 331.3 & $(474.4)$ & 288.8 & $(456.6)$ & -243.4 & $(627.8)$ & -392.9 & $(619.1)$ \\
\hline hsize & 7.197 & $(54.87)$ & 0.360 & $(52.06)$ & 163.8 & $(220.3)$ & 206.6 & $(217.0)$ & -88.37 & (339.9) & -64.42 & $(336.7)$ \\
\hline elec & 145.1 & (636.5) & 240.5 & (609.9) & 2,278 & $(2,390)$ & $4,492^{* *}$ & $(2,261)$ & $10,217^{* *}$ & $(4,267)$ & $9,890^{* *}$ & $(4,582)$ \\
\hline hh_age & 8.876 & (15.17) & 11.76 & (14.97) & -23.11 & $(82.49)$ & -42.91 & $(72.63)$ & -150.3 & (100.7) & $-192.6^{* *}$ & $(97.49)$ \\
\hline hh_female & 36.38 & (747.1) & 118.0 & (749.4) & 200.7 & $(2,588)$ & -71.97 & $(2,401)$ & 2,276 & $(5,483)$ & 2,084 & $(5,057)$ \\
\hline hh_nbyrscol & -26.10 & (48.72) & -2.818 & $(45.26)$ & -31.07 & $(242.9)$ & -76.11 & $(225.2)$ & 288.0 & (372.2) & 165.5 & $(318.5)$ \\
\hline priv & -580.5 & (489.7) & -571.4 & (458.5) & $-3,238$ & $(2,451)$ & $-3,318$ & $(2,415)$ & 3,234 & $(3,805)$ & 4,500 & $(3,646)$ \\
\hline credit_access & $1,103^{* * *}$ & (412.9) & $1,018^{* *}$ & (397.2) & 414.6 & $(1,712)$ & -432.2 & $(1,776)$ & $7,101^{*}$ & $(3,739)$ & 3,033 & $(2,940)$ \\
\hline warm_season & -131.5 & $(2,721)$ & -214.5 & $(2,653)$ & $-2,244$ & $(46,057)$ & $-5,034$ & $(44,250)$ & 207.1 & $(211,685)$ & $-19,638$ & $(187,514)$ \\
\hline cold_se & $-1,715$ & $(2,576)$ & $-1,591$ & $(2,579)$ & 3,778 & $(52,913)$ & 3,007 & $(51,254)$ & 24,343 & $(258,910)$ & 2,108 & $(225,438)$ \\
\hline Guiers lake & -569.1 & $(3,290)$ & 1,826 & $(3,171)$ & 11,588 & $(9,392)$ & 13,749 & $(9,704)$ & & & & \\
\hline Taba Ahmedou area & $-1,615$ & $(1,477)$ & $-1,864$ & $(1,366)$ & 10,248 & $(7,913)$ & 6,968 & $(5,801)$ & & & & \\
\hline Ndelle area & -141.5 & $(1,094)$ & -67.31 & $(1,046)$ & 27,145 & $(21,206)$ & 28,526 & $(20,358)$ & & & & \\
\hline Pont Gendarme area & -464.6 & $(1,049)$ & -206.7 & $(1,047)$ & & & & & & & & \\
\hline Guidakhar area & -584.2 & $(1,630)$ & -394.7 & $(1,595)$ & $23,531^{* * *}$ & $(8,771)$ & $24,909^{* * *}$ & $(7,083)$ & 19,128 & $(13,198)$ & $21,897^{* *}$ & $(10,995)$ \\
\hline Gae area & 22.42 & $(1,798)$ & 50.94 & $(1,764)$ & $18,869^{* *}$ & $(8,282)$ & $20,063^{* *}$ & $(8,262)$ & 12,607 & $(12,395)$ & 10,304 & $(8,742)$ \\
\hline Bokhol area & -444.7 & $(1,750)$ & -397.0 & $(1,765)$ & $18,009^{* * *}$ & $(7,504)$ & $18,857^{* * *}$ & $(7,628)$ & 13,602 & $(11,102)$ & $11,952^{*}$ & $(7,218)$ \\
\hline Mbilor area & 1,573 & $(1,037)$ & 1,460 & $(1,016)$ & $11,977^{* * *}$ & $(5,599)$ & $11,150^{* *}$ & $(5,377)$ & $-25,289$ & $(25,419)$ & $-13,621$ & $(23,587)$ \\
\hline Mboyo area & 1,330 & $(2,172)$ & 2,667 & $(2,204)$ & $21,543^{* *}$ & $(9,572)$ & $22,535^{* *}$ & $(9,714)$ & 13,558 & $(11,936)$ & 12,634 & $(7,757)$ \\
\hline Diatar area & 204.7 & $(2,270)$ & 421.7 & $(2,252)$ & $26,331^{* *}$ & $(10,762)$ & $28,718^{* *}$ & $(11,660)$ & & & & \\
\hline Donaye area & $-1,042$ & $(1,981)$ & -363.0 & $(1,914)$ & $19,462^{* *}$ & $(8,135)$ & $22,777^{* *}$ & $(8,794)$ & 5,190 & $(11,223)$ & 1,866 & $(7,841)$ \\
\hline Guede Chantier area & -728.9 & $(2,195)$ & 177.8 & $(2,061)$ & $17,519^{* * *}$ & $(7,068)$ & $20,817^{* * * *}$ & $(7,807)$ & 11,609 & $(9,753)$ & 10,300 & $(6,494)$ \\
\hline Guia area & $-1,155$ & $(2,012)$ & -682.9 & $(1,977)$ & $23,242^{* * *}$ & $(7,991)$ & $26,508^{* * *}$ & $(8,597)$ & 15,525 & $(10,652)$ & $12,251^{*}$ & $(6,938)$ \\
\hline Diagambal area & $-1,584^{*}$ & (909.2) & $-1,423$ & (893.8) & & & & & & & & \\
\hline Ndiareme area & $-1,442$ & $(2,031)$ & $-1,241$ & $(2,015)$ & $18,382^{* *}$ & $(8,946)$ & $22,873^{* * * *}$ & $(8,568)$ & 17,675 & $(10,828)$ & $13,290^{*}$ & $(7,074)$ \\
\hline Constant & 3,244 & $(8,028)$ & 5,725 & $(7,760)$ & 18,138 & $(45,775)$ & 8,208 & $(45,756)$ & 104,096 & $(166,849)$ & 107,487 & $(163,479)$ \\
\hline$\overline{\text { Obse }}$ & 443 & & 447 & & 146 & & 146 & & 173 & & 173 & \\
\hline $\mathrm{R}^{2}$-adjusted & 0.219 & & 0.204 & & 0.369 & & 0.320 & & 0.306 & & 0.256 & \\
\hline
\end{tabular}

Notes: Robust standard errors in parentheses; ${ }^{* * *} \mathrm{p}<0.01,{ }^{* *} \mathrm{p}<0.05,{ }^{*} \mathrm{p}<0.1$; Reference variable planting: inline; Reference variable for soil preparation: offsettage; Reference variable for season: wintering; Reference variable for area: Ross Bethio. 
Table 5. Summary of effects and standardized coefficients of significant explanatory variables from production function results

\begin{tabular}{|c|c|c|c|c|c|c|}
\hline \multirow{2}{*}{ Variables } & \multicolumn{2}{|c|}{ Rice } & \multicolumn{2}{|c|}{ Onion } & \multicolumn{2}{|c|}{ Tomato } \\
\hline & (1) & (2) & (1) & (2) & (1) & (2) \\
\hline larea & $\begin{array}{c}- \\
(0.207)\end{array}$ & $\begin{array}{c}- \\
(0.226)\end{array}$ & $\begin{array}{c}- \\
(0.380)\end{array}$ & $\begin{array}{c}- \\
(0.418)\end{array}$ & $\begin{array}{c}- \\
(0.255)\end{array}$ & $\begin{array}{c}- \\
(0.235)\end{array}$ \\
\hline qseedha & & & $\begin{array}{c}- \\
(0.140)\end{array}$ & $\begin{array}{c}- \\
(0.150)\end{array}$ & & \\
\hline com_seed & & & & & $\begin{array}{c}- \\
(0.140)\end{array}$ & \\
\hline fert_chem & $\begin{array}{c}+ \\
(0.081)\end{array}$ & & $\begin{array}{c}- \\
(0.216)\end{array}$ & & & \\
\hline qfertiliserha & & & & $\begin{array}{c}+ \\
(0.248)\end{array}$ & $\begin{array}{c}+ \\
(0.171)\end{array}$ & \\
\hline pricking & & & & & $\begin{array}{c}- \\
(0.122)\end{array}$ & \\
\hline qweeding & $\begin{array}{c}- \\
(0.049)\end{array}$ & $\begin{array}{c}- \\
(0.045)\end{array}$ & & & $\begin{array}{c}- \\
(0.103)\end{array}$ & $\begin{array}{c}- \\
(0.105)\end{array}$ \\
\hline chocagri & $\begin{array}{c}- \\
(0.106)\end{array}$ & & & & & \\
\hline elec & & & & $\begin{array}{c}\mathbf{+} \\
(0.237)\end{array}$ & $\begin{array}{c}+ \\
(0.262)\end{array}$ & $\begin{array}{c}- \\
(0.002)\end{array}$ \\
\hline hh_age & & & & & & $\begin{array}{c}+ \\
(8.234)\end{array}$ \\
\hline credit_access & $\begin{array}{c}+ \\
(0.150)\end{array}$ & $\begin{array}{c}- \\
(0.078)\end{array}$ & & & $\begin{array}{c}+ \\
(0.153)\end{array}$ & \\
\hline
\end{tabular}

Note: The - and + signs represent the effect of coefficients for the significant variables only; Standardized coefficients are provided in parenthesis in absolute value. 
Table 6. Profit function results using OLS (dependent variable: profitha)

\begin{tabular}{|c|c|c|c|c|c|c|c|c|c|c|c|c|}
\hline \multirow{3}{*}{ Variables } & \multicolumn{4}{|c|}{ Rice } & \multicolumn{4}{|c|}{ Onion } & \multicolumn{4}{|c|}{ Tomato } \\
\hline & \multicolumn{2}{|c|}{ (1) } & \multicolumn{2}{|c|}{ (2) } & \multicolumn{2}{|c|}{ (1) } & \multicolumn{2}{|l|}{ (2) } & \multicolumn{2}{|l|}{ (1) } & \multicolumn{2}{|c|}{ (2) } \\
\hline & Coeff & SE & Coeff & SE & Coeff & SE & Coeff & SE & Coeff & SE & Coeff & SE \\
\hline price & $4,067^{* * *}$ & $(365.1)$ & $4,012^{* * *}$ & $(366.0)$ & $11,618^{* * *}$ & $(1,297)$ & $11,417^{* * *}$ & $(1,336)$ & $15,227^{* * *}$ & $(5,569)$ & $14,553^{* * *}$ & $(5,149)$ \\
\hline yield & $142.3^{* * *}$ & (7.457) & $141.2^{* * *}$ & (7.390) & $77.56^{* * *}$ & (3.544) & $77.47^{* * * *}$ & (3.663) & $51.03^{* * *}$ & (2.217) & $50.93^{* * *}$ & $(2.204)$ \\
\hline$U C_{-}$seed & -0.444 & $(0.495)$ & & & $-0.487^{* *}$ & $(0.221)$ & & & $-0.0349^{*}$ & $(0.0206)$ & & \\
\hline UC_fertiliser & 1.500 & (3.542) & & & $15.57^{* *}$ & $(6.756)$ & & & 0.508 & $(0.612)$ & & \\
\hline UC_insecticide & -1.845 & (1.364) & & & $-5.709^{* *}$ & (2.363) & & & -2.987 & $(3.321)$ & & \\
\hline UC_weeding & -0.0111 & $(0.210)$ & & & -1.283 & $(2.762)$ & & & 1.428 & (1.372) & & \\
\hline UC_hiredlabour & $-31.01^{* * *}$ & (11.28) & & & -20.21 & (21.00) & & & -21.16 & (13.87) & & \\
\hline warm_season & 29,860 & $(23,134)$ & 36,071 & $(22,801)$ & $-350,408^{* * *}$ & $(94,614)$ & $-310,979^{* * *}$ & $(68,468)$ & 177,235 & $(155,483)$ & 193,042 & $(191,060)$ \\
\hline cold_season & $-102,100$ & $(83,794)$ & $-120,533$ & $(80,137)$ & $-309,932^{* * *}$ & $(93,183)$ & $-251,205^{* * *}$ & $(53,433)$ & 26,293 & $(136,348)$ & 54,540 & $(178,911)$ \\
\hline Guiers lake area & $-185,859^{*}$ & $(110,484)$ & $-191,230^{*}$ & $(110,590)$ & $1.322 \mathrm{e}+06^{* * *}$ & $(214,084)$ & $1.418 \mathrm{e}+06^{* * *}$ & $(168,845)$ & & & & \\
\hline Taba Ahmedou area & $257,286^{*}$ & $(140,585)$ & $235,538^{*}$ & $(132,286)$ & $1.981 \mathrm{e}+06^{* * *}$ & $(241,371)$ & $2.095 \mathrm{e}+06^{* * *}$ & $(209,630)$ & & & & \\
\hline Ndelle area & $-80,011$ & $(53,000)$ & $-97,163^{* *}$ & $(44,680)$ & $750,011^{* * *}$ & $(172,353)$ & $824,773^{* * *}$ & $(147,758)$ & & & & \\
\hline Pont Gendarme area & 13,834 & $(57,734)$ & $-15,024$ & $(54,089)$ & & & & & & & & \\
\hline Guidakhar area & $-24,186$ & $(60,670)$ & $-51,829$ & $(57,177)$ & $677,637^{* * *}$ & $(166,367)$ & $751,576^{* * *}$ & $(147,654)$ & $-665,105^{* * *}$ & $(151,113)$ & $-712,099^{* * *}$ & $(144,931)$ \\
\hline Gae area & $-72,122^{*}$ & $(41,665)$ & $-94,257^{* *}$ & $(39,050)$ & $840,590^{* * *}$ & $(136,340)$ & $922,854^{* * *}$ & $(109,145)$ & $-161,136$ & $(104,106)$ & $-211,918^{* *}$ & $(84,609)$ \\
\hline Bokhol area & $-92,247^{* *}$ & $(40,460)$ & $-115,668^{* * * *}$ & $(37,227)$ & $632,425^{* * *}$ & $(140,189)$ & $695,356^{* * *}$ & $(112,723)$ & $-271,261^{* * * *}$ & $(101,880)$ & $-304,494^{* * * *}$ & $(84,369)$ \\
\hline Mboyo area & $-112,663$ & $(122,472)$ & $-108,279$ & $(125,501)$ & $933,205^{* * *}$ & $(158,545)$ & $994,087^{* * *}$ & $(107,560)$ & $-82,876$ & $(118,138)$ & $-127,852$ & $(121,911)$ \\
\hline Diatar area & $-229,968^{* * * *}$ & $(62,833)$ & $-250,078^{* * * *}$ & $(60,617)$ & $816,538^{* * * *}$ & $(176,791)$ & $883,529^{* * * *}$ & $(157,279)$ & & & & \\
\hline Donaye area & $-54,271$ & $(63,727)$ & $-83,311$ & $(61,708)$ & $881,394^{* * *}$ & $(167,455)$ & $956,867^{* * *}$ & $(131,593)$ & $-128,437$ & $(154,452)$ & $-146,593$ & $(144,110)$ \\
\hline Guede Chantier area & $-168,421^{* * * *}$ & $(59,687)$ & $-191,763^{* * * *}$ & $(58,788)$ & $1.015 \mathrm{e}+06^{* * * *}$ & $(159,319)$ & $1.118 \mathrm{e}+06^{* * *}$ & $(137,370)$ & $-38,474$ & $(107,431)$ & $-55,927$ & $(95,961)$ \\
\hline Guia area & $-110,721^{*}$ & $(56,643)$ & $-140,909^{* *}$ & $(55,005)$ & $979,152^{* * *}$ & $(145,621)$ & $1.021 \mathrm{e}+06^{* * *}$ & $(114,886)$ & $-251,151^{*}$ & $(150,055)$ & $-294,279^{* * *}$ & $(144,998)$ \\
\hline Diagambal area & $-17,202$ & $(51,066)$ & $-61,972$ & $(46,626)$ & & & & & & & & \\
\hline Ndiareme area & $-99,065$ & $(67,446)$ & $-141,845^{\text {** }}$ & $(65,025)$ & $927,479^{* * *}$ & $(168,786)$ & $1.015 \mathrm{e}+06^{* * *}$ & $(133,111)$ & $-109,607$ & $(105,789)$ & $-143,147$ & $(98,369)$ \\
\hline Constant & $-750,856^{* * *}$ & $(80,493)$ & $-754,347^{* * * *}$ & $(78,901)$ & $-1.871 \mathrm{e}+06^{* * *}$ & $(289,208)$ & $-2.039 \mathrm{e}+06^{* * *}$ & $(211,323)$ & $-1.169 \mathrm{e}+06^{* * * *}$ & $(358,268)$ & $-1.175 \mathrm{e}+06^{* * *}$ & $(361,886)$ \\
\hline Observations & 500 & & 500 & & 170 & & 170 & & 185 & & 185 & \\
\hline $\mathrm{R}^{2}$-adjusted & 0.814 & & 0.809 & & 0.887 & & 0.880 & & 0.861 & & 0.856 & \\
\hline
\end{tabular}


Table 7. Summary of effects and standardized coefficients of significant explanatory variables from profit function results

\begin{tabular}{|c|c|c|c|c|c|c|}
\hline \multirow{2}{*}{ Variables } & \multicolumn{2}{|c|}{ Rice } & \multicolumn{2}{|c|}{ Onion } & \multicolumn{2}{|c|}{ Tomato } \\
\hline & (1) & (2) & (1) & (2) & (1) & (2) \\
\hline price & $\begin{array}{c}+ \\
(0.542)\end{array}$ & $\begin{array}{c}+ \\
(0.534)\end{array}$ & $\begin{array}{c}+ \\
(0.392)\end{array}$ & $\begin{array}{c}+ \\
(0.386)\end{array}$ & $\begin{array}{c}+ \\
(0.243)\end{array}$ & $\begin{array}{c}+ \\
(0.232)\end{array}$ \\
\hline yield & $\begin{array}{c}+ \\
(0.790)\end{array}$ & $\begin{array}{c}+ \\
(0.784)\end{array}$ & $\begin{array}{c}+ \\
(0.831)\end{array}$ & $\begin{array}{c}+ \\
(0.830)\end{array}$ & $\begin{array}{c}+ \\
(0.923)\end{array}$ & $\begin{array}{c}+ \\
(0.921)\end{array}$ \\
\hline UC_seed & & & $\begin{array}{c}- \\
(0.078)\end{array}$ & & $\begin{array}{c}- \\
(0.043)\end{array}$ & \\
\hline UC_fertiliser & & & $\begin{array}{c}+ \\
(0.033)\end{array}$ & & & \\
\hline UC_insecticide & & & $\begin{array}{c}- \\
(0.069)\end{array}$ & & & \\
\hline UC_weeding & $\begin{array}{c}- \\
(0.074)\end{array}$ & & & & & \\
\hline UC_total & & & & $\begin{array}{c}- \\
(0.082) \\
\end{array}$ & & \\
\hline
\end{tabular}

Note: The - and + signs represent the effect of coefficients for the significant variables only; Standardized coefficients are provided in parenthesis in absolute value. 
Figure 1. Map of the survey area

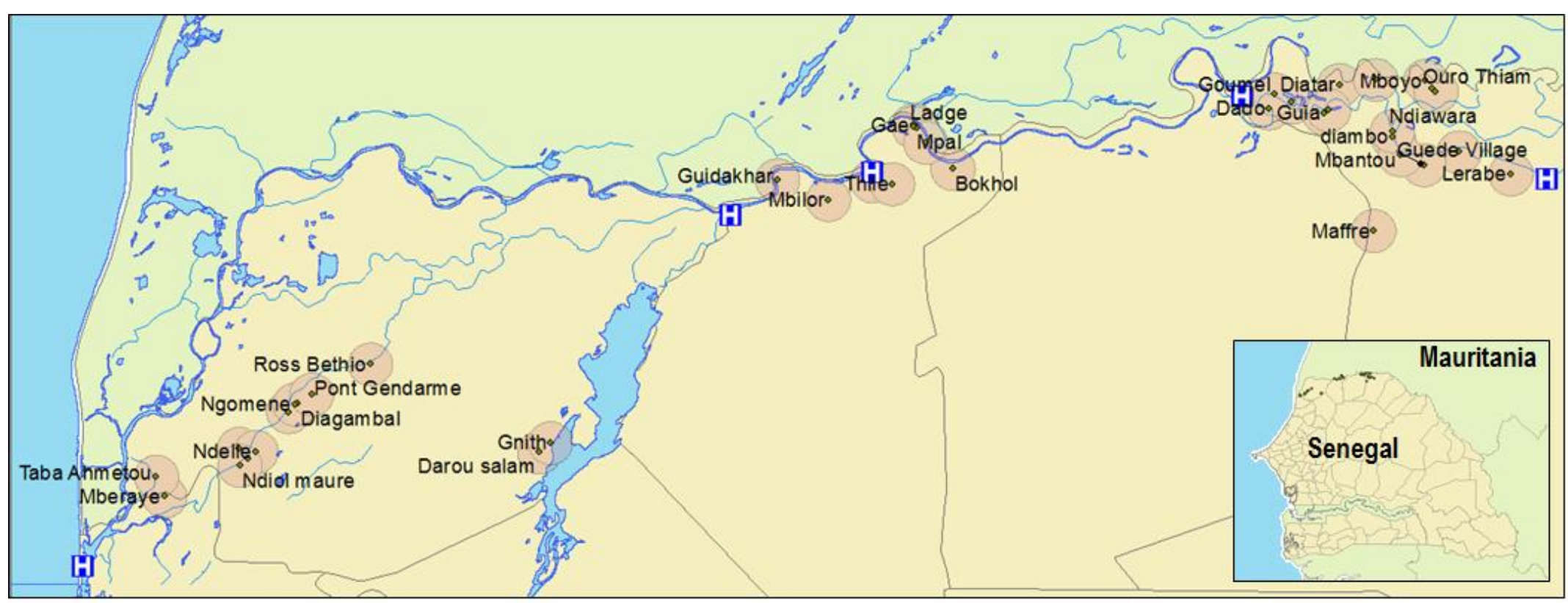

Notes: the green points represent the villages surveyed (overlapping labels for some villages are not shown). The light red circles represent the 3km radius around villages used to estimate weather data averages. The hospitals signs respresent the location of hospitals and health centers used as proxy for urban centers. 